\title{
Internationalization Business Models and Patterns of SMEs and MNEs: A Qualitative Multi-Case Study in the Agrifood Sector
}

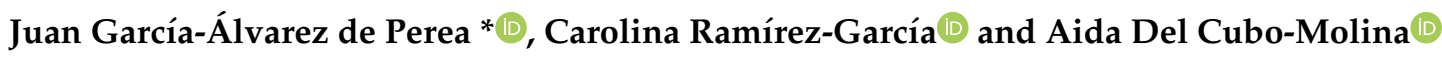 \\ Department of Financial Economics and Accounting, Pablo de Olavide University, Carretera de Utrera Km 1, \\ 41013 Seville, Spain; cramgar@upo.es (C.R.-G.); adelmol@upo.es (A.D.C.-M.) \\ * Correspondence: jgaralv@upo.es; Tel.: +34-954-977-921
}

Received: 1 April 2019; Accepted: 7 May 2019; Published: 14 May 2019

\begin{abstract}
Small- and Medium-sized Enterprises (SMEs) and Multinational Enterprises (MNEs) in the agri-food sector have been overcoming internationalization barriers. However, research is scarce, specifically to meet the Sustainable Development Goals, despite the importance of the sector. The main aim of our study is to explore the archetypes and internationalization pace of internationalized SMEs and MNEs in the agri-food sector, adopting an external perspective and an empirical approach. More particularly, the influence of the interaction of demand-side innovation and management control systems (MCSs) in companies in the industry is examined. A qualitative research design was developed in order to achieve an in-depth understanding of the contextual factors affecting international SMEs and MNEs in the agri-food sector. Semi-structured telephone interviews were conducted with three SME and three MNE managers. Our findings suggest that SMEs are not fundamentally different from MNEs - both types of organizations best fit the Casino model archetype. It was also found that strong competition helps the development of collaborative innovation, directing advancement toward fulfilling consumer demand. MCSs are neither communicating information nor managing perceived risks by creating trust and confidence; they are mostly used for diagnostic purposes, not substantially influencing the innovation process.
\end{abstract}

Keywords: international SMEs; international business models; internationalization archetypes; management control systems; innovation

\section{Introduction}

Small- and Medium-sized Enterprises (SMEs) are the backbone [1] of the European Union's (EU) economy: $99.8 \%$ of the enterprises that operated in the EU-28 non-financial business sector in 2016 were SMEs. They employed 93 million people, accounting for $67 \%$ of the total employment in the EU-28 non-financial business sector, and generating $57 \%$ of value additions in the EU-28 non-financial business sector [2]. The growth and innovation potential of SMEs will be decisive for the future prosperity of the EU [3-6].

Research on SMEs' internationalization may be described as unsystematic and fragmented, with a lack of conceptual clarity and non-cumulative progress [7-9]. SMEs are structurally different from Multinational Enterprises (MNEs), behaving differently [9], especially with regard to their competences, market behavior, and strategies [7]. "In terms of the internalization theory of the firm-issues of governance and location theory are in need to development, the question of dynamics and predicting the direction, speed and process of internationalization is unsatisfactory at least in some theorists' eyes" [8]. One of the consequences of this increasingly globalized world is that it has significantly enhanced opportunities to sell products abroad [10], with SMEs progressively internationalizing [11]. 
Internationalization is becoming a crucial condition not only for survival but also for the success of most agri-food firms [12]. SMEs and MNEs are overcoming internationalization barriers, which could be internal (such as inadequate human capital; financial constraints; a lack of foreign market exposure; and limited technical expertise) and external (for example, a country's policies and regulatory environment, its competitive dynamics, a lack of access to network resources, and liabilities of foreignness [13]. They need to enter international markets, helped by the technological advances of electronic communication and the Internet. The globalization process has resulted in a higher density of interdependencies and interactions: between a rising number of globally acting players. MNEs are complex and geographically dispersed organizational systems [14]. SMEs' limited capabilities and market presence make it more difficult to access innovative technology, an impediment avoided by setting alliances and collaborations with both buyers and suppliers [15]. The literature suggests that the traditional view of MNEs as big global monoliths and SMEs as relatively isolated niche-specialists has to be changed in a context in which smaller MNE-subunits with greater autonomy and globalizing SMEs progress to build interdependencies on a worldwide basis [16]. MNEs can be described more as interorganizational groupings than unitary organizations [14]. SMEs use their networks to combat size-related disadvantages, but that is not done by growth; rather, the networks enable them to remain small and independent, while further strengthening their position as small producers [17].

The agri-food sector is characterized by a large number of micro-, small-, and medium-sized enterprises [18]. It is one of the most contributing industries in the EU and is highly significant in terms of economic output and employment [19]. Despite the importance of the agri-food sector, research is scarce [12]. Spanish MNEs may be characterized as late internationalizers and concentrating their Foreign Direct Investment stock in their 'natural markets': the European Union and Latin America [20]. The food industry is the main manufacturing industry in Europe, representing 15.6\% of total sales and over one-third of world trade in agricultural products and food [11]. The Spanish agri-food sector has an undeniable weight in the Spanish economy, with a 3\% contribution to the Spanish GDP and representing $20 \%$ of the manufacturing industry [21]. Moreover, its Gross Value Added exceeded 30,000 million euros in 2017 [22]. The business structure of the sector consists of more than 29,000 companies, mostly small, with fewer than 10 workers. However, large companies are gaining weight: in $2017,24 \%$ of large industrial companies belonged to the agri-food sector, four new ones were created with more than 500 workers and 980 companies linked to this sector were incorporated [22]. This supply industry is predominantly made up of numerous SMEs, which have a weak bargaining position with buyers. Cooperation among these SMEs has recently increased, concerning R\&D activities, promotion, scheduling of production, and sales $[15,23]$. Recently, it has been suggested that, in the case of Spanish agri-food companies, the export variable is positively related to company performance and innovation [19]. The development of exports in the Spanish food and drink industry suggests a significant swing towards internationalization. The removal of barriers to entering the EU intensified the degree of internationalization and the importance of this sector for Spain [11].

Although agri-business companies are dominated by SMEs worldwide, MNEs play an important role in this industry. For instance, multinational subsidiaries constitute a potential source of social capital for SMEs that can help in the internationalization process. Limits on information exchange and trust hamper collaboration between SME and MNE subsidiaries. Facilitation by a neutral agency, for instance, may help to overcome these barriers [24]. SMEs can overcome the barrier of small size in their internationalization process through collaborative networks [25]. In the globalization era, firms of all sizes are beginning to share the same competitive space. For instance, symbiotic arrangements are evolving through which smaller firms enter the value chains of larger firms, in a good deal for both sides of the transaction [26]. Collaboration allows firms to overcome inherent constraints of size and to achieve the efficiencies required for global competition [26]. Despite the importance of the agri-food industry in the international markets, the research in this sector has been very limited in comparison with studies covering other sectors. 
Sustainability's significance has led to it becoming a priority on the political scene [27]. The resolution, 'Transforming our World: the 2030 Agenda for Sustainable Development' [28], including its 17 Sustainable Development Goals (SDGs) and 169 targets, was adopted on 25 September 2015 by Heads of State and Government at a special UN summit. The Agenda is a commitment to eradicate poverty and achieve sustainable development by 2030 worldwide, ensuring that no one is left behind. This commitment reflects how mankind takes action in order to achieve a sustainable planet [29]. The adoption of the 2030 Agenda was a landmark achievement, providing for a shared global vision towards sustainable development for all [30-32]. All countries have a shared responsibility to achieve the SDGs, and all have a meaningful role to play locally, nationally as well as on a global scale [27]. Goal 2 seeks to end hunger and all forms of malnutrition and to achieve sustainable food production by 2030. It is premised on the idea that everyone should have access to sufficient nutritious food, which will require widespread promotion of sustainable agriculture, a doubling of agricultural productivity, increased investments, and properly functioning food markets [33]. The SDGs explicitly call on all businesses to apply their creativity and innovation to solve sustainable development challenges [34]. The UN Global Compact (GC) is the most widely accepted principle-based initiative, enabling voluntary participation of firms in sustainability activities [35]. However, internationalization of the firm does not seemingly have an effect on GC principles' implementation [36].

Internationalization literature has focused on MNEs; yet, SMEs are structurally different from MNE [9]. The two more cited internationalization models in the literature are the Uppsala model and the born-global model [8,37-41]. The Uppsala Model, 'through a fortuitous combination of timing within the intellectual trajectory of the international business field and the model's inherent characteristics, it has evolved from a model with refutable hypotheses to become a 'paradigm' in the Kuhnian sense' [40]. 'The Uppsala approach examines the influence of organisational learning on internationalisation whilst internalisation theorists concentrate on the effect of innovation on internationalisation. Perhaps the interaction of all three processes is a way forward, but the precise causality is problematic.' [8]. It may be argued that the main advantage of the Uppsala Model, its general validity, may also be the model's main weakness, since the predictive power is difficult to be rigorously test [42].

In the field of internationalization and firm performance, prior research underplays the roles of management $[43,44]$. Future research should also consider the effects of variables related to the organizational environment and context that may influence internationalizing firms [9]. Researchers [45] made a call to study the role of international and market-specific social capital in a sample including both SMEs and large MNEs, in order to gain deeper knowledge of the process of opportunity exploitation and firm internationalization. Another call was made [46] to search for differences between SMEs and larger exporters, whose advantages in resources give them more options for internationalization and may make other information characteristics, such as integration or aggregation, more salient. It is also necessary to provide better contextualization of new research results and theory building. International business scholars have a fragmented understanding of the different forms MNE-SME cooperation can take [47]. There is an increasing number of autonomous economic actors taking the shape of decentralized units of MNEs; and SMEs are competing and cooperating in the global context [16]. Subsidiary initiatives are critical because they may firmly contribute to effective resource allocations within the MNE network [48]. MNEs may trade off a part of the independent management control associated with their large size to gain flexibility and scale economies; SMEs may choose to sacrifice some of their autonomy by integrating into the MNE's supply chain, to gain the necessary efficiency for a world-scale competitiveness [26].

A contingency approach is recommended, since the range of the firms' internationalization decisions, incorporating product decisions, market choice, and entry modes, are made in a holistic way [49]. In contingency theory, there is no single best way to organize an MNE; optimal MNE governance depends on the nature of each environment in which the MNE operates [50]. Internationalization research has been primarily confined to an empirical examination of either MNCs or SMEs rendering cross-sector comparisons difficult. However, agri-food sector SMEs depend heavily on their networks 
for various reasons [17]. The cooperation of companies within the sector can also be applied to societal challenges, such as achieving the United Nations' Sustainable Development Goals [47]. Our current assessment of the trajectory toward achieving the 17 UN SDGs by 2030 does not instill optimism. However, the SDGs foster a shift to a partnering-centered, opportunity-based, and more positively framed ambition aimed at developed as well as developing countries [51]. Ties between SMEs and MNE subsidiaries hold importance, not only in already thriving business settings but also, potentially, for wider economic development [24]. For instance, while poverty alleviation is a broader socio-economic initiative, businesses play an important part in the process because they sell to, employ, or can be formed by people residing in poor nations [52]. It is therefore important, in order to help companies meet the SDGs, the contribution of the agri-food sector.

In this research, the main aim of our study is to explore, adopting an external perspective and an empirical approach, the contextual factors explaining internationalization patterns and pace of SMEs and MNE in the agri-food sector. We try to provide an integrated perspective, paying attention to the collaborative relationships in place, which is relatively under-explored in the extant academic literature. More specifically, we are attempting to understand the influence of the interaction of demand-side innovation and management control systems (MCSs) in the companies of the industry.

Our findings suggest that SMEs are not fundamentally different from MNEs, both types of organizations best fitting the Casino model archetype. Firms are trying to minimize risks and exploit market opportunities, looking for new opportunities anywhere leading to higher probabilities of profits. The internationalization pattern is apparently taking the form of waves of internationalization. It was also found that strong competition is helping the development of collaborative innovation, directing innovation toward fulfilling- consumer demand. MCSs are neither communicating information nor managing perceived risks by creating trust and confidence; they are mostly used for diagnostic purposes, not substantially influencing the innovation process. The industry does not seem to fit any of the Child et al. (2017) international business models, and could being classified in an intermediate category between traditional market-adaptive and technology-exploiter.

Despite the exploratory nature of this study, some useful implications can be drawn. This paper intends to offer several contributions. First of all, we have found no significant differences between SMEs' and MNEs' international business models and risk tolerances, with both types of organizations best fitting the Casino model archetype. Additionally, a new intermediate type of SME international business models was identified. Finally, it also calls for a deeper study of the facilitator role of public policies, fostering innovation that contributes to SDGs, in the context of the agri-food sector, among other avenues for further research suggested.

The article is structured as follows: Section 2 provides a summary of current research in the field. The focus here is on internationalization theories, specifically addressing the mainstream models (The Uppsala model and the born global model), innovation issues, MCSs and the specificities of the agri-food sector. In Section 3, the research method employed is described in detail. Section 4 presents the findings obtained, derived from the study of the content analysis. Lastly, Section 5 presents relevant discussion, highlighting avenues for further research, and conclusions.

\section{Literature Review}

Internationalization theories are described below, followed by the main literature results concerning the agri-food sector. Since we are primarily interested in the links, if any, between MCSs and innovation in the agri-food sector, in the final subsection, the effect stated in previous literature from the use of MCSs in internationalizing companies, with a note on innovation context, is provided.

\subsection{Internationalization}

Although there was still insufficient knowledge about internationalization of new and small firms at the beginning of the century [53], research in the topic has increased over the last decade. A SMEs internationalization literature review conducted by Ruzzier et al. suggested an enhanced theoretical 
integrative conceptual model of international entrepreneurship based on four internationalization properties (mode, market, product, and time), while also discussing key antecedents and consequences of the internationalization process [54]. SMEs' internationalization process may bring economic growth to SMEs and improve their competitive advantages; however, it may give rise to new risks and uncertainties they shall face [9]. For instance, SMEs may adapt to local customs or apply the same policies abroad, in the latter situation raising the risk of appearing foreign and incompatible to local culture, limiting therefore their business opportunities [55]. Risk management is one of the most important internal processes, not only in large companies-it is believed that the strategic flexibility of MNEs has a significant effect on risk avoidance and overall value increase in MNEs in the international market-but also in SMEs [56].

Concerning the pace, internationalization has been traditionally considered an evolutionary process $[42,57]$. The ability to internationalize has become an imperative for many companies, allowing them to survive nowadays [58]. Internationalization patterns (both in terms of pace and modes) are influenced by several dimensions [39]. The internationalization process of SMEs derives from the combined action of a number of internal and external factors [37,59-61]; which appear in the stages of business activity at several levels [62]. The two more cited internationalization models are the Uppsala model and the born global approach [8,37-41]. In addition to these models, three perspectives have dominated international business research over the past four decades [42]: Dunning's framework, transaction costs and internalization theory $[8,41,63]$. The proponents of these theoretical perspectives although competing on the model's supremacy, have also attempted to reconcile their different views [42].

The Uppsala model explains internationalization as a sequential process $[8,9,37,39,40,42,57,64]$. Therefore, the present stage of internationalization is relevant to explain the future path of internationalization. They differentiate in the model between two groups of state variables: capability variables and commitment/performance variables, both of which are the result of-and affect-the change variables. In the initial version of the model, the state variables ('firms' existing commitment and experiential knowledge) are the basis for decisions to commit resources to international operations that in turn shape the change variables of the model (future operational performance and processes of learning [42]. "The Uppsala model is a micro-level tool of analysis that essentially provides a holistic explanation of MBE evolution' [64] (p. 1089). It also provides a starting point for a better comprehension of relationships and networks' impact on firm internationalization [65]. The augmented model in 2017 suggests that intermittent decision processes related to committing resources and continuous knowledge development processes are the starting points for change [64]. The dimensions of the commitment process include reconfiguring and coordinating (opportunity development: includes both identification of opportunities and its implementation). 'In general terms, this would warrant further managerial intervention through the committing of resources in order to support smoother functioning, e.g., where units have an information advantage' [64] (p. 1093). Concerning the knowledge development processes, they rely on concepts of social construction and sense-making. The innovation process may be characterized as uncertain and dynamic, following a trial-and-error process, based on experiential learning and identifying and making use of opportunities. Trust-building is a crucial sub process of the knowledge development process from this point of view [64]. In the model, a dynamic capability is an ability to "integrate, build and reconfigure internal and external competencies to address rapidly changing environments", while "commitments" describes the distribution of resources over the MNE's functions, its product lines, the countries where it is active, and the relationships in which it has invested [64]. The term also has a forward-looking connotation: positions reflect commitments to particular courses of action. In contrast, "performance" refers to what has been achieved already. Both connotations are relevant and they are present simultaneously, and both will determine the scope and content of the ensuing knowledge development processes discussed above. Relevant dimensions of resource positions and performance depend on the context and the focal issue of a particular research process. For example, the status of the firm in its network may be a focal dimension, reflecting both its 
resource position and performance outcomes. The degree of globalization is sometimes considered a relevant performance variable, and also a meaningful measure of the firm's resource position that drives the potentially virtuous circle of MBE evolution [64].

The born global approach applies to firms that are internationally oriented since their inception or soon after, who view the world as their marketplace and are usually small firms with limited tangible resources, but significant intangible resources and capabilities $[9,37,66-69]$. The main differences of both approaches are summarized in the Table 1 below:

Table 1. Mainstream models characteristics of the internationalization process.

\begin{tabular}{ccc}
\hline Model & Uppsala & Born Global \\
\hline Internationalization & After domestic market & World is their domestic market \\
\hline Behavioral assumption & $\begin{array}{c}\text { Risk aversion, } \\
\text { uncertainty avoidance }\end{array}$ & $\begin{array}{c}\text { Entrepreneurial, } \\
\text { proactive risk taking }\end{array}$ \\
\hline $\begin{array}{c}\text { Advantages from } \\
\text { internationalization }\end{array}$ & Economies of scale & Market dominance in global niches \\
\hline $\begin{array}{c}\text { Key capabilities in } \\
\text { international expansion }\end{array}$ & $\begin{array}{c}\text { Experiential knowledge, } \\
\text { network position }\end{array}$ & $\begin{array}{c}\text { Flexible, innovative adaptation to } \\
\text { foreign market opportunities }\end{array}$ \\
\hline $\begin{array}{c}\text { Approach to internationalization } \\
\text { opportunity recognition }\end{array}$ & Effectuation, opportunity creation \\
\hline $\begin{array}{c}\text { Internationalization } \\
\text { Pattern }\end{array}$ & Sequential & Quick expansion from foundation \\
\hline
\end{tabular}

Despite its general acceptance, the Uppsala model has been widely criticized. When critiques of international business (IB) research with a focus on whether IB scholarship tackles "big questions" was reviewed [41], a shift of IB research towards "grand challenges" in global business was suggested, fostering the use of interdisciplinary research methods, multilevel approaches, and phenomena-driven perspectives to attain the goal.

One concern is not considering the impact of the digital context, and the role of the individual, which are required in a more robust theory [39]. In this sense, 'modern digital technologies have changed the very manner by which firms arrange production and engage with customers. In a digital firm, the nature of the offer, the distribution channels, the structure of the value chain, the pricing strategy (and even the currency itself, i.e., cryptocurrency) may differ fundamentally from those of a traditional MNE' [39] (p. 1152).

Besides, the recognition of different logics and patterns of internationalization helps to increase our understanding of the phenomenon [40]. It might be argued that internationalization patterns show companies' overall resource allocation strategies and not isolated incremental commitment changes [40]. According to their Casino Model proposed, companies are characterized as opportunity seeking, looking for economies of growth, where key capabilities in international expansion are the managerial skills and administrative systems to manage foreign activities. They suggest that faced with uncertainty and partial ignorance about foreign markets, firms limit their exposure to downside outcomes by internationally diversifying. This behavior also allows the firm to rapidly explore, discover, and act upon opportunities in several markets. A firm's propensity to engage in international diversification is clearly contingent on the quantity of available financial and other resources at its disposal. In addition, the quality of resources matters in international strategy [40]. Not all entry opportunities can be pursued, forcing managers to rank-order and prioritize. Evaluating the performance of individual market entries is difficult. The Casino Model shares certain characteristics of the Uppsala and born-global models, combined in a distinctive pattern according to a different strategic logic [40]. Their international expansion is less restrained by cautious uncertainty avoidance: once internationalized, the marginal costs of engaging a new agent or of setting up a new sales subsidiary are no longer significant. Like in born global firms, decisions on international expansion are 
means-oriented and opportunity seeking, but in existing — rather than creating-markets. The companies will enter markets, both through agents and through foreign direct investment, in a wave-like fashion, when the capabilities to manage the firm's international expansion have been set. Companies have a similar approach to internationalization as in the born global approach, and the internationalization pattern takes the form of waves of internationalization [40].

Another criticism is that the model is not able to explain non-linear and discontinuous dynamics of the process over time. Additionally, the model does not provide researchers with testable propositions [42]. According to their approach, internationalization may be considered as an evolutionary process, so that non-linear and discontinuous dynamics of internationalization processes may be addressed when the roles of novelty and selection mechanisms are considered. In this sense, new resource commitments may create novelty and therefore deviate from a gradual path of growth as firms take higher risks, and are consequently obliged to deal with selection pressures. Outcomes are moderated by the resources a firm can draw upon in its ecosystem and by the volatility of its environment [42].

Another contribution to the literature on SME internationalization was made 'by reconciling existing frameworks and demonstrating that traditional manufacturing SMEs can follow various paths of international expansion' [37] (p. 1052). The knowledge on this topic also increased when a new and systematic analysis of the likely associations between decision modes, information use, and network attachment among internationalizing SMEs was developed [70]. The knowledge domain of the SME and the international experience of its key decision-maker were used to contextualize the analysis. A model distinguishing between international and market-specific social capital based on internationalization process theory and social network theory has also been proposed [45]. Using data on 239 internationalizing SMEs, their results show a mediated effect of international social capital on opportunity exploitation via market-specific social capital. Consequently, an internationalization process for social capital development in international business opportunity exploitation was identified. International social capital is conceptualized as a firm's network of international relationships and the internationalization knowledge accumulated in interactions with these relationships. Although in this globalized world, with advances in information and communication technologies, it is easier to find new international business opportunities for SMEs, exploiting them is more challenging than ever, since market-specific knowledge is more difficult to obtain and retain. Social capital and corporate governance theories have been jointly applied to explain the scope of family SMEs' internationalization [71]. Trying to overcome the traditional in literature family/non-family dichotomy to understand the effect of ownership and management on family SME internationalization, they adopt the distinction between family-influenced and family-controlled SMEs. They also analyzed management involvement (family managers only vs. family and external managers). According to their research, professional managers externally recruited from outside the family are mainly important in the case of lower levels of family ownership. However, according to their findings is the combination of external capital with external managers that really works. Using panel data of 187 Taiwanese SMEs that expanded abroad [44], it was found that age, educational level, international experience, and duality of the CEO have moderating effects on the relationship between internationalization and firm performance.

Three international business models were found by Child et al. (2017): traditional market-adaptive, technology-exploiter, and ambidextrous explorer, the factors explaining the model adopted being industry, level of home economy development, and decision-maker international experience [72]. The traditional market-adaptive international business model seems to be less risky and costly in comparison to the more technological innovation-based models. In this model, their links and relationships with suppliers are notably significant for two reasons: Suppliers are an important source of innovation when there is little internal R\& D; and the supplier has a significant impact on the speed and delivery capability of SMEs. For market-adaptive SMEs, innovation does not play a prominent role in their international business mode. On the contrary, technology-exploiter SMEs' business models tend to be driven by an entrepreneur's recognition of new technical possibilities to meet market needs, the business model generally being demand-led. Finally, the ambidextrous explorer companies work 
with long life cycle products, preceded by a lengthy period of development. Firms commit significant $R \& D$ resources to develop new innovation, but there may be limited product adaptation to different markets [72].

Recent research has also provided a better understanding of the firm's internationalization strategy and enabled us to compare the firm with other strategic groups [73]. This study allows the classification of firms in one of the four following groups: Marketer (firms interested in international markets mainly as target markets for their products); investor (firms that exploit to a greater extent comparative advantages associated with localizing activities in foreign markets); networker (internationalization strategy mainly focused on network resources); and weak internationalizer (firms whose international business remains secondary to them).

Finally, MNEs and SMEs differ in their structure and behavior [9]. In comparison to SMEs, the main advantage of MNEs derives from the assets that they control through ownership [45], by establishing foreign subsidiaries abroad and therefore creating an internalized organization across borders. SMEs are on the contrary more flexible and quicker to adapt to new market conditions $[37,38,45,69]$. Not only is little known about the characteristics of these internationalized companies in their later life, but also empirical literature is lacking [38]. The relationship between a company's internationalization and performance is a crucial area of research not only for academics, but also for professionals and politicians [12,44]. The internationalization of SMEs has attracted growing attention as a subject not only of academic research but also as a goal of public policy [70]; and the role of public administrations that collaborate with the internationalizing SMEs has become a more visited field of study $[37,74]$. Export promotion instrument and services (EPSs) palliate institutional voids and facilitate SMEs entry and expansion into emerging economies [75], which contributed to the internationalization and risk literature by revealing that SMEs motivations and use of EPSs depend on their degree of internationalization and attitude toward risks. 'Policy-makers need to build greater awareness of the firms' different needs with respect to internationalization. Such differences could be useful for segmenting firms and adapting support services and promotion programmes to the specific needs of each type of company.' [73] (p. 294).

\subsection{Agri-Food Sector}

To be successful, internationalization is required in the agri-food sector [12]. The industry is dealing with major challenges posed by the sector's economic and non-economic environments, changes in lifestyles and food consumption, and by global growth [76]. The agri-food sector is characterized by a large number of micro and SMEs [18], being one of the most important sectors in the European Union. Its contribution in terms of economic output and employment is highly significant [19]. Moreover, it plays a leading role in the Spanish economy. One of the consequences of this increasingly globalized world is opportunities to sell companies' products abroad being significantly enhanced [10]. This is due to, among others, the enlargement of the European Union (EU), technological innovations that allow for the transportation of perishable products across large distances, and rapidly vanishing barriers to trade [77]. Internationalization is becoming a crucial condition for not only the survival but also the success of most agri-food firms. Agri-food companies may be found in one of the next three stages: (1) Export firms with low profits, due to the initial costs incurred in exporting [12]; (2) companies with a more advanced internationalization process that benefit from the positive outcomes of operating on a larger scale; and (3) highly international, geographically diversified companies whose performance decreases as a result of the costs of entering extra-regional markets, higher transition costs and organizational complexity. The internationalization of Spanish agri-food companies has increased in the past decades $[10,12]$, mainly because of lower transaction costs from the removal of trade barriers, and the uniformity of food safety regulation in the European region [12].

An analysis of the relationship between internationalization and performance, using micro-level data from the agri-food sector, identified the following factors that explain the success of a company in comparison with its competitors [77]: Technology and Production-Related Factors; Market research; 
Product Innovation; Relationship quality; Retail Closeness and Consumer Closeness; Bargaining Power, Staff qualification and Foreign Market Engagement. However, the agri-food sector is considered a low-tech intensive industry, where innovating firms grow more quickly and obtain higher returns than non-innovators $[18,19]$. Despite relatively low R\&D investments, innovation is needed in this global context. Several reasons explain why firms in this sector tend to innovate: to stand out from their competitors; to fulfil the needs and expectations of their customers; to sustain prosperity; to attain long-term goals; and to develop competitiveness in today's global markets $[18,19]$. The industry seems to be addressing the challenges in this globalized world for the sector with a shift towards pull innovation that reflects considerable collaboration [78]. Food firms are mainly process-innovation oriented [79] and both product and process innovation are to a large extent characterized by incremental rather than radical changes [80]. Most agri-food innovations apparently are due to customer and retailer demands, marketing strategies, consumer perception of quality and safety and environmental pressure [19]. In the agri-food sector, internationalization strategies aiming to emphasize the authenticity of the origin of a product may not lead to any improvement in market share. In this case, quality products may need alternative strategies based on two main aspects: product innovation and new network development [81].

When the geographical proximity impact of the Spanish agri-food industry was analyzed in a regional study, it was found that geographical proximity between agri-food companies and industrial states and R\&D centers has a significant impact on firms' absorptive capacities whereas geographical distance to large companies and transport facilities play an important role in determining $R \& D$ activities [82]. In this sector, in SMEs participating in networks, the higher the network assistance received from an external network, the greater is the innovation performance of SMEs [83]. In addition, literature has also revealed that SMEs exhibiting higher innovation performance have more export intensity than that of moderately innovative or low-innovative SMEs [83].

It has also been suggested in literature that innovation can be developed in companies in which MCSs create trust and confidence. Vertical coordination in food networks is characterized by dynamically changing supply and marketing relationships [84]. E-business provides support and improvement options for vertical coordination processes in food networks. Nevertheless, for the adoption of e-business in food networks, the essential question is how to communicate information content to support the transaction decision and to manage perceived risks by creating trust and confidence [84].

The field of the role of public administrations that collaborate with the internationalizing SMEs $[37,74]$ in the agri-food sector programs of public funding for innovation have been studied [85]. It was found that food companies that obtain public funding tend to have a more innovative profile than agriculture ones. Additionally, they gain easier access to regional funding, harder when it comes to state funding. Policies should include assistance at the start of the internationalization process and an attempt to prolong the strategy until the volume of business is sufficient to start showing an increase in performance (such as the promotion of networking between Spanish and foreign companies to reduce the costs of more global internationalization strategies) [12].

\subsection{The Use of MCSs in Internationalizing Companies}

The potential impact of MCSs on innovation and internationalization is considered now. The accounting literature discloses contradictory results on the effect the different uses of MCSs have on innovation [10,46,86-88]. Previous research has summarized and synthesized the evidence on SME innovation, exporting and growth [89], explaining internal and external (eco-system) enablers, as well as the interplay between innovation and exporting in SME growth. According to prior research, there is a strong positive association between innovation, exporting, and performance in terms of productivity and/or growth; innovation and exporting appear to work jointly to improve performance, and there is also a substantial element of interdependence and self-selection in this process [89]. SMEs have advantages in terms of rapid decision-making, willingness to take risks, and flexibility in 
responding to new market opportunities (behavioral advantages); while larger firms have advantages linked to scale and the availability of specialist resources (material advantages) [89].

Enablers may be classified as internal and external. In the former, we can find skills, leadership and people management; research and development activities; capital investment and equipment; internal financing; design; intellectual property management; leadership and strategy. Broadly sustained by evidence are high-quality skills (technical, networking and team-working), R\&D, capital investments and strong liquidity. The latter shall be distinguished between external factors increasing the knowledge base of the firm and resource-enhancing factors, to overcome internal resource constraints [89]. Three channels to increase the knowledge base are being there, openness and learning by exporting. Concerning resource-enhancing factors to overcome internal resource constraints, public sector grants and loans are the main factor. Public support is also crucial to overcome information asymmetries or the costs of entering export markets. The evidence is more consistent in the cases of openness; stronger eco-systems where SMEs have greater absorptive capacity; targeted public support for innovation and export; demand-side factors; and public procurement [89].

'The performance measurement has proven to be a difficult task, especially in agrifood chains.' [90] (p. 53). In the field of internationalization and firm performance, prior research underplays the roles of management $[43,44]$. MCSs are administrative devices that gather, interpret, and communicate useful information for managers in decision-making [10]. Sharing IT and accounting information are a means for both partners in a relationship to gain a competitive advantage [88]. MCSs are mainly used to measure and reward performance by supervising the accomplishment of objectives [87]; but alongside this monitoring function, MCSs' coordinating functions generate, update, and share the information needed to reduce uncertainty, to direct attention, and assist planning [87].

Four dimensions of information have been identified to impact managing interorganizational relationships: scope (narrow to broad), timeliness (slow/standard to fast/customized to requests), aggregation (summarized to very detailed), and integration (one-unit information to multiple-unit information) [91,92].

Simons [93] emphasizes the relevance of the style of use of control systems, distinguishing diagnostic control systems (used on an exception basis to monitor and reward achievement of specified goals through the review of critical performance variables or key success factors) and interactive control systems (used to expand opportunity-seeking and learning) [93,94]. In contrast to diagnostic controls, what characterizes interactive controls is senior managers' strong level of involvement. Through interactive control systems, top managers send messages to the whole organization in order to focus attention on strategic uncertainties [94]. Simons' 'levers of control' framework indicates that an interactive use of management control systems contributes to fostering successful product innovation [93]. However, other researchers suggest this may be the case only in low-innovating firms, while the effect is the opposite in high-innovating firms [94], the impact of innovation on performance being moderated by the style of use of MCSs.

In international business relationships, the scope and timeliness of information directly affect relationship quality, and that the intensity with which this information is used-in diagnostic or interactive ways-to some extent reinforces these positive associations. It is suggested that exporting firms should devote more effort to developing formal control systems that generate timely information [46].

Individual MCSs are able to enhance or create organizational capabilities. They have a positive and direct effect on exports, enhancing the development of international strategies, improving organizational export commitment, and providing employees with a flexible but stable frame of reference [10]. MCSs can also help build trust: when used not only to supervise but also to coordinate, MCSs avoid possible suspicions that could damage trust [87].

However, this significant potential role of MCS is neglected according to empirical evidence, and it is suggested that exporting firms should devote more effort to developing formal control systems that generate timely information [46]. 


\section{Methodology}

As the purpose of this article is to generate deeper and richer insights into the role of contextual factors affecting internationalization of SMEs and MNEs in the agri-food sector, a qualitative research design was developed [95-97]. The current study is, therefore, primarily exploratory in nature [98]. Following the literature review, field research was conducted using a multi-case study approach [96], trying to obtain a broad generalization [99] based on evidence from different single case studies, while presenting findings and conclusions. Case studies allow the researcher to grasp a holistic understanding of the phenomenon under investigation $[96,97]$. The goal is to explore the factors contextualizing the internationalization process of companies. This context is analyzed since it rarely appears in the academic literature with high scientific impact [100]. The research design enables a broader understanding of the topic and encourages further research in this field. This applies in particular to the agri-food sector, where previous research is scarce. Yin [96] suggests that a case study can consist of a single or multiple study for the understanding of the phenomenon. The case study methodology is an appropriate strategy for studying contemporary phenomena in real-life contexts, and is assumed to encompass other contextual conditions related to the cases. Focusing on qualitative methods is the main road for advancing the internationalization theory [49,64]. For the field of agribusiness, case study research has been deemed appropriate and successfully applied [17,101-104]. A full and transparent account of the process of analysis used to transform the set of data emanating from the interview-based study into a well-founded, coherent and illuminating narrative, was kept [105].

\section{Sample Selection}

Data was collected from the region of Andalusia in Southern Spain, where agri-food sector companies are the leading actors of the reorientation of the productive model in Andalusia, playing a prominent role in the foreign sector and industry [106]. Limiting our research to Andalusian SMEs and global MNEs permits to discount the institutional effects from differences between companies in diverse regions [82]. We relied on a purposive sample of Andalusian agri-food companies. The chosen sample of firms from the Andalusian agri-food sector is considered a suitable empirical setting for the study. This sector is the most important one in their economy [22,107]. There are more than 6000 companies belonging to 2900 producers, representing around $10 \%$ of the Andalusian Gross Domestic Product (GDP) [22]. The sector has continuously grown during recent years, mainly due to the continued growth of exports [22,107]. Over $60 \%$ of the production of these firms is exported, and the sector witnessed in the 1990s an intensification of environmental practices and the application of several environmental management systems [108]. According to leading executives of the agri-food sector in Andalusia, international expansion is considered to be the main lever of growth of their company (78\% of survey respondents) [22]. The commitment to geographic expansion finds its reflection in the investment plans of the companies surveyed, which is the main investment priority for $22 \%$ of respondents, behind only cost-efficiency process plans (30\%). Internationalization and cost efficiency are intrinsically related, since $67 \%$ consider that competitiveness in costs and/or prices is the main factor when competing in the global market [22]. Over the past two decades, this sector has experienced considerable growth in sales to new foreign markets $[15,108]$.

Theoretical sampling was used to choose our research sample $[109,110]$. The case study approach has been criticized, arguing that it provide little basis for scientific generalization [96,111,112]. The advantages gained by increasing the number of cases are countered by certain disadvantages, so it is recommended to include more cases as long as they increase the explanatory power of the research $[96,105,111,113-116]$. Therefore, six companies were chosen, providing a representation of the sector suitable for the study [117]. Companies consider their network relationships important; exports revenues account for more than $60 \%$ of their total turnover; and were heavily internationalized. One of the companies chosen was a MNE subsidiary, which would otherwise qualify as a SME. Another was a cooperative which had solved size problems by adopting this organizational form. 
Access was obtained to three SME and three MNE managers, of whom half were men and half were women. The more information the sample holds, relevant for the actual study, the lower number of participants is needed $[115,116]$. Due to confidentiality issues, the participating organizations are anonymous in the paper.

The main characteristics are provided in Table 2. All of the interviewees had a managerial position (CEO, Sales Manager or Export Manager), the companies chosen having a solid international record. While gaining access to the companies, participant time commitment and information confidentiality was stressed, in order to help establish routine-based trust [118].

Semi-structured telephone interviews were scheduled for around an hour; interviews had a common structure and were conducted in an open manner, with free-flowing discussions encouraged (interview transcriptions are available upon request). Qualitative data analysis programs, also known as Computer-Assisted Qualitative Data Analysis Software (CAQDAS), enabled systematic, iterative analysis, characterized by analytic links grounded in the data and the links with data being persistently maintained [119]. The data gathered in interviews was analyzed using software Atlas.ti 8.3.20. Atlas.ti helps to ensure rigor within the analytical process [120]. The interviews were transcribed and subsequently coded [121] with the software after using one of the interviews to standardize the coding process. The standardization process followed involved coding each paragraph and checking differences until an agreement was reached. Then the six interviews were coded by the main researcher. The process started with the inductive definition of codes covering the contextual factors affecting international SMEs and MNEs in the agri-food sector in this study [109,114,122]. As new codes emerged, all the data were recoded with the new code in mind, thereby following the constant comparative method of qualitative data analysis [109]. The eleven codes resulting from this process were: Customer relationships, distribution channels, information, innovation, internationalization degree, internationalization presence, key competitive factors, MCSs, public policies support, risks and suppliers. The process continued with a careful reading of a transcript and continued by its coding using the 11 codes mentioned before. The coding result of every interview subsequently analyzed was compared to those already performed in an attempt to assure the integrity of the coding scheme. One hundred and eighty six key texts were chosen and coded. An occurrence frequency analysis of the encoding process shows the number of coincidences of key texts in the encoding categories. Additionally, in order to understand the interaction between the contextualizing factors, co-occurring codes were analyzed. Query reports were generated using Atlas.ti and every paragraph with co-occurring codes was re-read and scrutinized to understand the interactions between the two codes. 
Table 2. Main characteristics of the companies under study.

\begin{tabular}{|c|c|c|c|c|c|c|c|}
\hline $\begin{array}{c}\text { Firm } \\
\text { Id. }\end{array}$ & Type of Company & $\begin{array}{l}\text { Interviewee's } \\
\text { Position }\end{array}$ & Interviewee's Training & $\begin{array}{l}\text { Interviewee's } \\
\text { Experience }\end{array}$ & $\begin{array}{l}\text { International } \\
\text { Presence }\end{array}$ & $\begin{array}{l}\text { Type of International } \\
\text { Channels }\end{array}$ & $\begin{array}{l}\text { Family or } \\
\text { Non-Family }\end{array}$ \\
\hline 1 & MNE & $\begin{array}{l}\text { Key Account } \\
\text { Manager \& } \\
\text { Foodservice }\end{array}$ & $\begin{array}{c}\text { Degree in Economics, } \\
\text { Master in International Economy; } \\
\text { Executive MBA }\end{array}$ & $\begin{array}{l}\text { More than } 15 \text { years in } \\
\text { several sectors }\end{array}$ & All around the world & $\begin{array}{l}\text { Retailers, Direct } \\
\text { customers }\end{array}$ & Non-family \\
\hline 2 & SME & Chief Sales Officer & $\begin{array}{l}\text { Business Administration Degree, } \\
\text { Master in International Commerce, } \\
\text { Master in Sales Management }\end{array}$ & $\begin{array}{l}\text { International Manager } \\
\text { in Pharmaceutical }\end{array}$ & European Union & Retailers & Family company \\
\hline 3 & $\begin{array}{c}\text { MNE (Which } \\
\text { subsidiary is a SME) }\end{array}$ & $\begin{array}{l}\text { CFO \& Chief } \\
\text { Logistics Officer }\end{array}$ & Business Administration Degree & 2 years in other sectors & $\begin{array}{c}\text { Mostly } \\
\text { European Union }\end{array}$ & Retailers & Non family \\
\hline 4 & SME (Cooperative) & $\begin{array}{l}\text { Key Manager - } \\
\text { International }\end{array}$ & Degree in Slavic Philology & $\begin{array}{l}10 \text { years in agri-food } \\
\text { sector Export positions }\end{array}$ & European Union & Retailers & Non family \\
\hline 5 & MNE & $\begin{array}{l}\text { CEO \& Sales } \\
\text { Manager }\end{array}$ & $\begin{array}{l}\text { Degrees in Business Administration, } \\
\text { Agri-Economics and Commerce }\end{array}$ & $\begin{array}{c}15 \text { years in } \\
\text { agri-food sector }\end{array}$ & All around the world & Wholesalers & Family group \\
\hline 6 & SME & Chief Sales Officer & Engineering Degree & $\begin{array}{l}15 \text { years in } \\
\text { medical sectors }\end{array}$ & Europe & $\begin{array}{l}\text { Retailers and } \\
\text { wholesalers }\end{array}$ & Family group \\
\hline
\end{tabular}




\section{Findings}

\subsection{Contextual Factors}

The occurrence frequency analysis of the encoding process is shown at Table 3 . There are no remarkable differences between SMEs and MNEs. The most frequent code of all, with 29 and 48 quotes, representing $22.14 \%$ and $24.38 \%$ of all quotes, was customer relationships. Information, risks and MCSs were the next most frequent codes. The relative frequency of information, innovation, key competitive factors and suppliers and customers is slightly lower in the case of SMEs, probably because they are more sensitive disclosures. The relative frequency of internationalization degree and MCSs (image issues) and distribution channels and public policies support (highlighting they are a little more important issues) are faintly higher.

Table 3. Absolute and relative code frequencies.

\begin{tabular}{|c|c|c|c|c|c|}
\hline SMEs & $\begin{array}{l}\text { Absolute } \\
\text { Frequency }\end{array}$ & $\begin{array}{c}\text { Relative } \\
\text { Frequency }\end{array}$ & MNEs & $\begin{array}{l}\text { Absolute } \\
\text { Frequency }\end{array}$ & $\begin{array}{c}\text { Relative } \\
\text { Frequency }\end{array}$ \\
\hline Customers & 29 & $22.14 \%$ & Customers & 48 & $24.38 \%$ \\
\hline Distribution Channels & 8 & $6.11 \%$ & Distribution Channels & 6 & $2.89 \%$ \\
\hline Information & 19 & $14.50 \%$ & Information & 32 & $16.34 \%$ \\
\hline Innovation & 5 & $2.29 \%$ & Innovation & 7 & $3.45 \%$ \\
\hline Internationalization degree & 6 & $4.58 \%$ & Internationalization degree & 6 & $2.83 \%$ \\
\hline Internationalization presence & 4 & $3.05 \%$ & Internationalization presence & 7 & $3.51 \%$ \\
\hline Key competitive factors & 5 & $3.82 \%$ & Key competitive factors & 10 & $5.34 \%$ \\
\hline MCSs & 21 & $16.03 \%$ & MCSs & 27 & $13.97 \%$ \\
\hline Public Policies Support & 6 & $4.58 \%$ & Public Policies Support & 4 & $1.81 \%$ \\
\hline Risks & 19 & $14.50 \%$ & Risks & 30 & $15.15 \%$ \\
\hline Suppliers & 11 & $8.40 \%$ & Suppliers & 20 & $10.31 \%$ \\
\hline Totals & 133 & $100.00 \%$ & Totals & 195 & $100.00 \%$ \\
\hline
\end{tabular}

Customer relationships was the most frequent code, highlighting their significance for both types of organizations. This importance was summarized by one of the MNEs interviewees:

"The organization is structured around clients and customized for clients".

When asked about their customer expectations, they said they expected a trust relationship. Another interviewee stated, " $(\ldots)$ and the customer is guaranteed the best product available in the market". On the same lines, a MNE's manager claimed that:

"We are a leading company in the sense that we offer different brands, different packaging concepts, different quality concepts, ( . . . ) we are a direct business, from the field practically to the table"; and also: "Well, what we expect from the customer is to continue growing together; because, as I said before, we grow if they are growing too".

An SME manager claimed that "... what we all look for is long-term fidelity and cooperation".

Information flows try to smoothen relationships with customers; as a SMEs manager explains, “( ... ) EDI is a computer system that both companies have (you have to register and pay for it) and through that we can say that our system is monitored daily ( ... ); any documentation or any record that is made can be rapidly reviewed". Showing trust issues, they share information with customers, but up to a certain extent:

"We do not fully share information but we do show the client details of the suppliers that work for them'; and another manager: "( ... ) with those we trust, we work better. Those who try to deceive us or give us wrong information, well ... that relationship should not last very long." Information for MNEs is key: "Analysis is mega important ( ... ) The demand of each product for each client, for each geographical area, is analyzed monthly by product; ( ... ) if fluctuation of demand in a particular product is noted, you have to look for alternatives so that it does not impact the profit and loss account. The most important resource is the management tools; and additionally we have a specialized team providing information". 
As a key competitive factor, adaptation to customer needs is a requirement, as indicated by one MNE manager:

"It is more than the needs of a client; ( . . ) it is also essential to anticipate a little bit the needs of the clients. It is fundamental to adapt; if you do not adapt you cannot move forward.' And also another manager ' ( . . ) we have to do something with packaging, with the format, with the intermediary'.

Another MNE manager argued that:

"(The industry) is adapting continuously; for example, if something new comes out, we have to study it at European level, since Europe is the legislation driver. (... ) We have to get all our factories to work out a solution first, and revise the patent, our own patent".

Demand changing requests are always satisfied: "now large companies, large associations, investment funds owning plantations in origin; then those companies operate under the umbrella of many certifications. Supermarkets demand those certifications so (...); we only buy from suppliers that are certified".

And a MNE manager declared:

"( ... ) have all the global certifications and everything that is required internationally to be able to export".

Nonetheless, an SME manager highlighted other factors:

“( ... ) a Premium brand in which we guarantee quality and service, above all. Also, we acquired a good portfolio of suppliers at the source of origin that allowed us to serve customers ( ... ); we have our own productions that allow us to have more strength in the sale". And "we mainly have (as advantage) the land we have, we can plant at any time of the year, and we can have our products available any month of the year".

Innovation was found to be essential for all companies in the study. SME managers posit that:

“( $\ldots$ ) the key factor of our company is innovation. If there is no innovation, we will not grow, and what you have to bet is for innovation, for R \& D; and to create new formulas and new formats that consumers demand, new products. That is the future of our company".

The other managers' first answer to what the key factors in their company were was:

"Innovation ... ". And "Innovation, and communication, obviously languages, closeness too".

In this sense, another MNE interviewee explained:

"The quality of the seed, that innovation, ( . . ) that is the key aspect for the company".

Trust again seems very important in the business, as a MNE manager argued: "We also do not cheat like other people who claim to be producers. We are not producers". In some cases, to earn customers' trust, SMEs are willing to make compromises:

"At the end of the year we earn money because we are not an NGO; but not all of the company's transactions are profitable. Let's also admit that there are also losses when problems occur. But service is more important than profit because, after all, the service will ultimately give you the profit."

Concerning MCSs, MNEs' use of Enterprise Resource Planning systems (ERPs) is enabling the diagnostic style use. One SME had an internally developed ERP. They integrated a balanced scorecard, within the internal ERP that they had developed. As a MNE manager stated: 
" (... ) the biggest problem we have now in such a big company is that we operate in many different and segmented countries, using different management systems. ( ... ) that is the reason to unify everything in SAP".

In SMEs, the use of MCS is even less. As a manager explained, “No, I don't know if ERPs are being used ... ; we do use an Excel table; ... comparing the years ... ". SMEs use budgets, based on historical costs, deviations being rare because estimations are usually reliable and accurate. They also have no incentives for suppliers because they offer quality products, with their premium brand being more important than the level and cost of production.

MNEs anticipate risks, assuming a proactive role. One of the MNE managers explained:

"Every supplier must be audited: if the audit is not passed, they do not work for us; ( . . ) the biggest challenge has been the approval of suppliers; ... the standards of the company were too strict for the standards of most Spanish companies".

This risk mitigation strategy is supported by a MNE manager, stating that:

"More than anything is about not having losses as ...; a sudden change of currency or legislation does not affect us negatively, because everything is covered".

Climate risk is also considered, even if it cannot be controlled by MNEs or SMEs. However, MNEs cover those risks, signing contracts long in advance. Another MNE manager highlights their anticipation of risks:

"How do we reduce the risk, right? It is about starting alliances with companies already consolidated in the market".

It is also remarkable that all companies are risk avoiders; SMEs prefer to open new markets with the support of Extenda (Andalusian Agency for Exports Promotion) and ICEX (Spanish Institute of Foreign Trade) rather than play a more active role by partnering or looking for other solutions. An SME commented on risks ahead:

"Farm offer is exceeding demand, so it's time to consolidate customer relationships and refine internal cost structures". And "We assume risks, it is important to provide at any cost, but we try to diminish as much as possible the risks we take."

They are also highly concerned about Brexit, taking into account the consequences of Russia's veto to their products. And, to summarize their views, a SME manager claimed:

"I prefer having less risk even if profits decrease a bit. ( . . ) Risks are a headache".

Finally, concerning suppliers, even for MNEs, gathering information is complicated and getting a supplier to participate in a survey is unfeasible:

"It is much better having a coffee with them when you visit the land, discussed in a five-minute talk; and you get more information, and more clear, than you would get from any survey".

This informal control on suppliers is also made by SMEs:

"Of course, when you visit the farmers of the seed you are told what problems you have, what could improve; but nothing formal, nothing in writing".

SMEs also look at the long-term relationship with suppliers: a SME manager, on managing conflicts with suppliers, shared that:

“( ... ) it can be very selfish to only care about you; you can try to work a solution out together with the supplier. And those who work it out, they perform better in the long term ... Occasionally, the supplier may win; but the long term relationship is what prevails.' 
The main similarities and differences found in the interviews between SMEs and MNEs are summarized in the Table 4 below:

Table 4. Similarities and differences between SMEs and MNEs.

\begin{tabular}{|c|c|c|}
\hline & Similarities & Differences \\
\hline Customers & $\begin{array}{l}\text { Central and key to their long-term } \\
\text { survival. Trust relationships }\end{array}$ & $\begin{array}{l}\text { SMEs are more flexible to } \\
\text { adapt to changes in social trends }\end{array}$ \\
\hline Distribution Channels & Mostly retailers & MNEs have more direct customers \\
\hline Information & Constant flows of information & $\begin{array}{l}\text { SMEs use more informal } \\
\text { methods to gather information }\end{array}$ \\
\hline Innovation & Key for all of them & $\begin{array}{l}\text { Focus on product innovation on MNEs; } \\
\text { focus on demand-side innovation on SMEs. }\end{array}$ \\
\hline Internationalization degree & $\begin{array}{l}60-80 \% \text { international sales; } \\
\text { fitting the Uppsala model }\end{array}$ & Only one SME fitting the Born Global model \\
\hline Internationalization presence & Consolidated in many countries & MNEs are worldwide, SMEs restricted to Europe \\
\hline Key competitive factors & $\begin{array}{l}\text { Innovation, product quality, } \\
\text { suppliers control, adaptation skills }\end{array}$ & $\begin{array}{l}\text { Size and being present worldwide are important in } \\
\text { MNEs; flexibility to adapt to customer changing } \\
\text { requests more important in SMEs }\end{array}$ \\
\hline MCSs & $\begin{array}{l}\text { Managers mainly use for } \\
\text { monitoring purposes }\end{array}$ & $\begin{array}{l}\text { Neglected role in SMEs, } \\
\text { except for the born global SME }\end{array}$ \\
\hline Public Policies Support & Support is needed & $\begin{array}{l}\text { Far more important for SMEs, } \\
\text { in order to open and settle in new markets }\end{array}$ \\
\hline Risks & Risk avoiders & $\begin{array}{l}\text { MNEs are more proactive risk managers, using more } \\
\text { tools, anticipating risks, trying to mitigate them. }\end{array}$ \\
\hline Suppliers & Long-term relationship, trust & SMEs use informal controls on suppliers \\
\hline
\end{tabular}

\subsection{Factors Interaction}

For the purposes of this paper, focus was laid on the relationships between MCSs, internationalization degree and innovation. Co-occurring codes were analyzed, in order to understand the interaction between the contextualizing factors. The co-occurrence texts analysis allows a deeper understanding of the interaction between different codes. Not surprisingly, the role of MCSs is neglected by interviewees, with no significant co-occurrences. Again, the results are quite similar, regardless of the type of company. Innovation for instance, allows companies to reach new markets and speed up the internationalization process. An SME manager thus commented on their international presence:

"Right now mainly European market, but soon we will have our own varieties, which allow us to send the fruit out of Europe to Asia and North America, Latin America perhaps, unfortunately you cannot reach Russia"

Another interesting point is that MNEs are keen on sharing information with customers:

“( .. ) preparing a series of reports, for suppliers and for clients to keep clients informed. We make meetings -every commercial manager-, he makes meetings with his clients to keep them informed; about trends, food ... We have material designed exclusively for clients."

An MNE manager pointed out the benefits of customer-shared information in innovation, when explaining how they achieve the highest quality:

" $(. .$.$) the customer's feed-back to know how you can improve that seed with the innovation$ that we are carrying out (...), that is what is important"

The co-occurrence results are presented in Table 5a,b. 
Table 5. (a) MNEs Co-occurrences and (b) SMEs Co-occurrences.

\begin{tabular}{|c|c|c|c|c|c|c|c|c|c|c|c|}
\hline \multicolumn{12}{|c|}{ (a) } \\
\hline & Customers & $\begin{array}{l}\text { Distribution } \\
\text { channels }\end{array}$ & Information & Innovation & $\begin{array}{c}\text { Internationalization } \\
\text { degree }\end{array}$ & $\begin{array}{l}\text { Internationalization } \\
\text { presence }\end{array}$ & $\begin{array}{l}\text { Key competitive } \\
\text { factors }\end{array}$ & MCSs & $\begin{array}{l}\text { Public policies } \\
\text { support }\end{array}$ & Risks & Suppliers \\
\hline Customers & 0 & 2 & 17 & 5 & 0 & 2 & 5 & 8 & 2 & 13 & 12 \\
\hline Distribution Channels & 2 & 0 & 1 & 0 & 0 & 1 & 0 & 0 & 1 & 2 & 0 \\
\hline Information & 17 & 1 & 0 & 3 & 0 & 0 & 0 & 9 & 0 & 6 & 7 \\
\hline Innovation & 5 & 0 & 3 & 0 & 0 & 0 & 2 & 0 & 0 & 2 & 1 \\
\hline Internationalization degree & 0 & 0 & 0 & 0 & 0 & 0 & 0 & 0 & 0 & 0 & 0 \\
\hline Internationalization presence & 2 & 1 & 0 & 0 & 0 & 0 & 0 & 0 & 1 & 2 & 1 \\
\hline Key competitive factors & 5 & 0 & 0 & 2 & 0 & 0 & 0 & 0 & 0 & 0 & 1 \\
\hline MCSs & 8 & 0 & 9 & 0 & 0 & 0 & 0 & 0 & 0 & 2 & 4 \\
\hline Public Policies Support & 2 & 1 & 0 & 0 & 0 & 1 & 0 & 0 & 0 & 0 & 1 \\
\hline Risks & 13 & 2 & 6 & 2 & 0 & 2 & 0 & 2 & 0 & 0 & 6 \\
\hline Suppliers & 12 & 0 & 7 & 1 & 0 & 1 & 1 & 4 & 1 & 6 & 0 \\
\hline \multicolumn{12}{|c|}{ (b) } \\
\hline & Customers & $\begin{array}{l}\text { Distribution } \\
\text { channels }\end{array}$ & Information & Innovation & $\begin{array}{l}\text { Internationalization } \\
\text { degree }\end{array}$ & $\begin{array}{l}\text { Internationalization } \\
\text { presence }\end{array}$ & $\begin{array}{l}\text { Key competitive } \\
\text { factors }\end{array}$ & MCSs & $\begin{array}{l}\text { Public policies } \\
\text { support }\end{array}$ & Risks & Suppliers \\
\hline Customers & 0 & 3 & 7 & 1 & 0 & 0 & 1 & 7 & 0 & 3 & 3 \\
\hline Distribution channels & 3 & 0 & 1 & 0 & 0 & 0 & 0 & 0 & 0 & 0 & 0 \\
\hline Information & 7 & 1 & 0 & 1 & 1 & 0 & 0 & 10 & 0 & 2 & 3 \\
\hline Innovation & 1 & 0 & 1 & 0 & 0 & 1 & 2 & 1 & 0 & 0 & 0 \\
\hline Internationalization degree & 0 & 0 & 1 & 0 & 0 & 0 & 0 & 0 & 0 & 0 & 0 \\
\hline Internationalization presence & 0 & 0 & 0 & 1 & 0 & 0 & 0 & 0 & 1 & 0 & 0 \\
\hline Key competitive factors & 1 & 0 & 0 & 2 & 0 & 0 & 0 & 0 & 0 & 0 & 1 \\
\hline MCSs & 7 & 0 & 10 & 1 & 0 & 0 & 0 & 0 & 0 & 1 & 5 \\
\hline Public policies support & 0 & 0 & 0 & 0 & 0 & 1 & 0 & 0 & 0 & 0 & 0 \\
\hline Risks & 3 & 0 & 2 & 0 & 0 & 0 & 0 & 1 & 0 & 0 & 0 \\
\hline Suppliers & 3 & 0 & 3 & 0 & 0 & 0 & 1 & 5 & 0 & 0 & 0 \\
\hline
\end{tabular}




\section{Discussion and Conclusions}

When analyzing the internationalization pattern, the shifting, digital, global world has changed how business is conducted and SMEs do not behave fundamentally different from MNEs, as was the norm earlier. Regardless of their different size and resources, they may share resource allocation strategies, in line with the Casino Model proposed by Håkanson and Kapen [40]. All companies in this study were found to have rational strategies in place to decrease the potential impact of poor results. They are looking for business opportunities, and rationally developing their skills and capabilities for international expansion. It might be argued that decades ago the world context was different; however, this internationalization pattern is the result of rational strategies. This was one SME's vision of the internationalization process:

“( . . ) it was almost out of necessity; we had a product that was not sold here in Spain ... So

it was complicated but it was out of necessity, because here in Spain it was not sold"

The companies in this study were found to have a similar approach to internationalization, trying to minimize risks and exploit market opportunities, placing more bets leading (keeping in mind there is a limit to the number of bets companies may make) to a higher probability of a win; and the internationalization pattern seemingly taking the form of waves of internationalization. Even the SME that best fits the born global characterization is considered a proactive opportunity taker rather than a proactive risk taker. Each new venture is carefully planned and risks are minimized, and the company's eggs are never placed in one basket, but diversified.

Business synergies arise from the sharing and common use of resources [123]. In line with previous research, firms in the sector have sought new ways of collaboration, such as scheduling of sales [123]. The cooperation in this study shows how entering into strategic alliances, collaborations and integration allows the company to reposition and stay competitive by increasing exports [124].

The industry does not seem to fit any of the Child et al. (2017) international business models. The interviews show how the industry has characteristics of both traditional market-adaptive and technology-exploiter models. It is true than they rely on their suppliers in some cases to develop new products to meet demands, and that their speed and delivery capability is key to the success of the industry. However, the industry is demand-driven and innovation plays a prominent role in their international business mode. They are looking for new technical possibilities to meet market needs. Constantly, different products and characteristics are sought after; pull innovation is revealed as a competitive strategy. The industry is characterized by risk-averse suppliers; the fact that they prefer a smaller, more stable income over a higher, more variable income challenging the innovation process. These findings are in line with previous research [125].

MCSs are neither communicating information nor managing perceived risks by creating trust and confidence. They are starting to devote more effort to developing formal control systems that generate timely information. However, although information has a broad scope, companies face problems in securing fast and customized request information. In the companies studied, the MCSs are basically used for diagnostic purposes, not substantially influencing the innovation process.

Finally, it has to be noted how one manager construed their dealings with suppliers (and the suppliers with the grower-packers) in terms of their attempts to be fair [88], providing cost justifications for the prices charged:

"Then everybody has a wrong idea or a lot of confusion; under these terms of selection people confuse the prices and take the profit for granted". And "... there is no price control and speculation is already created, that is impossible for us to stop".

We finally present the managerial and public policy implications of our research, country specific dimensions, and avenues for further research. 


\subsection{Managerial Implications}

In this globalized world, new opportunities for both MNEs and SMEs are arising due to recent innovations in information technology and strategic reorientation of technological change. Findings suggest that organizational engagement with position and paradigm innovation is not affected by either age or size [126]. The strong competitive environment is helping the development of collaborative innovation, directing product, process, and organizational innovation toward fulfilling consumer demand [78], as the cases in this study reveal. Products and attributes demanded are constantly changing, and managers should take advantage of the substantial opportunity for pull innovation to pay off as a competitive strategy [78].

However, collaboration does not end there. Companies can combine marketing campaigns and adopt joint measures helping the adoption of quality certifications required in foreign markets. As the cases reveals, relationships between exporting firms and wholesalers are developed with the aim of improving service to the retailer or even of achieving more direct sales. The cooperative case shows that these relationships also help improving bargaining power. Finally, there is also room for collaboration in joint research projects [123]. Several agri-food sector companies may deal with the demands of food retailers-reliable supply or quality requirements-, by choosing the right partners in a network. The innovative capacity of small companies operating in the agri-food sector is additionally constrained by limited organizational capabilities, ranging from a lack of strategic development, management deficiency, and an absence of clear vision [17].

Innovation is a clear element within the strategy of Andalusian agri-food companies. The traceability of the products appears as a fundamental piece for the safety and trust of the consumer. New technological tools are required to enhance traceability; new innovations may be developed collaboratively.

\subsection{Public Policy Implications}

The institutional setting (in its economic, cultural, and legal aspects) affects firms' ability to innovate [127]. Both MNEs and SMEs are dealing with significant barriers due to lack of information and trust. Policy measures should facilitate the development and enhancement of inter-firm ties. Fostering MNE linkages could facilitate capability development in new SME ventures [128], especially in settings where foreign direct investment is fading or local institutions are weak [129].

'Born global' firms present a significant challenge to public policy in support of internationalization [49]. Policymakers shall produce export support programmes, especially for SMEs focusing on encouraging cooperation between firms and research centers [25], to improve firm competitiveness, which allows SMEs to access foreign markets..

Public policies may also play a facilitator role, fostering innovation that contributes to Sustainable Development Goals, while helping agri-food companies fulfil their responsibilities to avoid harm [29].

\subsection{Country Specific Dimensions}

The analyzed sector features certain singular characteristics (such as type of products and suppliers), which should be considered when extrapolating the results to other industries. However, the results can be extrapolated to other countries, such as Italy, where the agri-food sector has similar characteristics. Anyway, as noted before, our findings from the exploratory research need to be empirically tested using a larger sample of firms and in a wider geographical context.

\subsection{Avenues for Further Research}

Future research [47] can enlarge the sample to generate more robust conclusions. A qualitative approach was adopted and the present research is an explorative one: it is intended to provide insights from which hypotheses might be developed. Future research should obtain larger samples, develop finer-grained hypotheses and test those using appropriate statistical techniques. It could be interesting to compare other sectors as well. 
The strategic decision-making process should be studied in depth in these conditions of global environmental uncertainty. It is relevant to investigate how to communicate information content to support the transaction decision and to manage perceived risks by creating trust and confidence [88].

In addition, and since innovation is consumer-driven, it can also be investigated how public policies can support-with R\&D incentives-improvements in public concerns such as traceability, human health and environmental quality.

Finally, the study of why the role of MCSs is neglected nowadays, in a competitive environment where controlling costs is even more important, is another avenue for research.

Author Contributions: J.G.-Á.d.P. conceived the study; J.G.-Á.d.P., C.R.-G. and A.D.C.-M. designed the methodology; J.G.-Á.d.P., C.R.-G., and A.D.C.-M. analyzed the data; C.R.-G., and A.D.C.-M. helped funding resources, J.G.-Á.d.P. wrote the original draft preparation, J.G.-Á.d.P., C.R.-G. and A.D.C.-M. provided review and editing; J.G.-Á.d.P. administered the project. J.G.-Á.d.P., C.R.-G. and A.D.C.-M. have read and approved the final manuscript.

Funding: This research was funded by Spanish Ministry of Economy and Competitiveness, grant number ECO2014-57023-P; and by the Andalusia Regional Government, grant numbers SEJ111 and SEJ1933. And The APC was also funded by the same grants.

Acknowledgments: The authors would like to thank Juan Manuel Ramón Jeronimo for his constructive and helpful suggestions on early versions of the paper.

Conflicts of Interest: The authors declare no conflict of interest. The funders had no role in the design of the study; in the collection, analyses, or interpretation of data; in the writing of the manuscript, or in the decision to publish the results.

\section{References}

1. Ivanova Ruffo, O.; Mnisri, K.; Morin-Esteves, C.; Gendron, C. Judgements of SMEs' Legitimacy and Its Sources. J. Bus. Ethics 2018, 1-16. [CrossRef]

2. European Commission. Annual Report on European SMEs 2016/2017: Focus on Self Employment; European Commission: Brussels, Belgium, 2017; ISBN 9789279741265.

3. Eurobarometer, F. Internationalisation of Small and Medium-Sized Enterprises; European Commission: Brussels, Belgium, 2015; ISBN 9789279505591.

4. Entrepreneurship Unit Directorate-General for Enterprise and Industry European Commission. Internationalization of European SMEs; European Commission: Brussels, Belgium, 2010.

5. Commission of the European Communities. A "Small Business Act" for Europe; COM(2008) 394 Final; European Commission: Brussels, Belgium, 2008.

6. Cernat, L.; Norman-López, A.; T-Figueras, A.D. SMEs Are More Important than You Think!_Challenges and Opportunities for EU exporting SMEs; European Commission: Brussels, Belgium, 2014.

7. Ribau, C.P.; Moreira, A.C.; Raposo, M. SME internationalization research: Mapping the state of the art. Can. J. Adm. Sci. 2018, 35, 280-303. [CrossRef]

8. Buckley, P.J. The contribution of internalisation theory to international business: New realities and unanswered questions. J. World Bus. 2016, 51, 74-82. [CrossRef]

9. Knight, G.A.; Liesch, P.W. Internationalization: From incremental to born global. J. World Bus. 2016, 51, 93-102. [CrossRef]

10. Gomez-Conde, J.; Lopez-Valeiras, E. The dual role of management accounting and control systems in exports: Drivers and payoffs. Span. J. Financ. Account. 2017, 47, 307-328. [CrossRef]

11. Guili, H.E.; Ferhane, D. Internationalization of SMEs and Effectuation: The Way Back and Forward. Proceedings 2018, 2, 1422. [CrossRef]

12. Serrano, R.; Fernández-Olmos, M.; Pinilla, V. Internationalization and performance in agri-food firms. Span. J. Agric. Res. 2018, 16, e0107. [CrossRef]

13. Oparaocha, G.O. SMEs and international entrepreneurship: An institutional network perspective. Int. Bus. Rev. 2015, 24, 861-873. [CrossRef]

14. Ghoshal, S.; Bartlett, C.A. The Multinational Corporation as an Interorganizational Network. Acad. Manag. Rev. 1990, 15, 603-625. [CrossRef] 
15. Galdeano-Gómez, E.; Pérez-Mesa, J.C.; Aznar-Sánchez, J.A. Internationalisation of Smes and Simultaneous Strategies of Cooperation and Competition: An Exploratory Analysis. J. Bus. Econ. Manag. 2016, 17, 1114-1132. [CrossRef]

16. Borghoff, T.; Welge, M.K. Globalization: The Evolution of Enterprises in the Global Network Competition. Organ. Soc. 2001, 8, 1-20. [CrossRef]

17. Brinkmann, P.; Håkansson, A.; Butiene, I.; Kjærsgard, H.; Mortensen, B.K.; Martens, J.; Müller-Hansen, B.; Petrenko, A. The use of networks as a strategic approach of micro-enterprises in the agri-food sector. Int. J. Entrep. Innov. 2014, 15, 169-178. [CrossRef]

18. Kühne, B.; Vanhonacker, F.; Gellynck, X.; Verbeke, W. Innovation in traditional food products in Europe: Do sector innovation activities match consumers' acceptance? Food Qual. Prefer. 2010, 21, 629-638. [CrossRef]

19. Zouaghi, F.; Sánchez, M. Has the global financial crisis had different effects on innovation performance in the agri-food sector by comparison to the rest of the economy? Trends Food Sci. Technol. 2016, 50, $230-242$. [CrossRef]

20. Mayordomo, X.M.; Espinosa-Méndez, C.; Araya-Castillo, L. When geography matters: International diversification and firm performance of Spanish multinationals. BRQ Bus. Res. Q. 2018. [CrossRef]

21. FIAB. Informe Economico. Industria de Alimentación y Bebidas; FIAB: Madrid, Spain, 2018.

22. KPMG. IV Estudio del Sector Agroalimentario de Andalucia; KPMG: Madrid, Spain, 2018.

23. Galdeano-Gómez, E. Exporting and environmental performance: A firm-level productivity analysis. World Econ. 2010, 33, 60-88. [CrossRef]

24. Prashantham, S.; McNaughton, R.B. Facilitation of links between multinational subsidiaries and SMEs: The Scottish Technology and Collaboration (STAC) initiative. Int. Bus. Rev. 2006, 15, 447-462. [CrossRef]

25. Serrano, R.; Acero, I.; Fernandez-Olmos, M. Networks and export performance of agri-food firms: New evidence linking micro and macro determinants. Agric. Econ. 2016, 62, 459-470. [CrossRef]

26. Etemad, H.; Wright, R.W.; Dana, L.P. Symbiotic International Business Networks: Collaboration between Small and Large Firms. Thunderbird Int. Bus. Rev. 2001, 43, 481-499. [CrossRef]

27. Carrasco, I.; Buendía-Martínez, I. From the Business Strategy Result to a Source of Economic Development: The Dual Role of CSR. J. Small Bus. Strateg. 2016, 26, 69-87.

28. United Nations. A/RES/70/1-Transforming Our World: The 2030 Agenda for Sustainable Development. 2015. Available online: https://www.unfpa.org/resources/transforming-our-world-2030-agenda-sustainable-development (accessed on 13 May 2019).

29. Voegtlin, C.; Scherer, A.G. Responsible Innovation and the Innovation of Responsibility: Governing Sustainable Development in a Globalized World. J. Bus. Ethics 2017, 143, 227-243. [CrossRef]

30. Leal Filho, W.; Azeiteiro, U.; Alves, F.; Pace, P.; Mifsud, M.; Brandli, L.; Caeiro, S.S.; Disterheft, A. Reinvigorating the sustainable development research agenda: The role of the sustainable development goals (SDG). Int. J. Sustain. Dev. World Ecol. 2017, 25, 131-142. [CrossRef]

31. Leal Filho, W.; Tripathi, S.K.; Andrade Guerra, J.B.S.O.D.; Giné-Garriga, R.; Orlovic Lovren, V.; Willats, J. Using the sustainable development goals towards a better understanding of sustainability challenges. Int. J. Sustain. Dev. World Ecol. 2019, 26, 179-190. [CrossRef]

32. Xia, B.; Olanipekun, A.; Chen, Q.; Xie, L.; Liu, Y. Conceptualising the state of the art of corporate social responsibility (CSR) in the construction industry and its nexus to sustainable development. J. Clean. Prod. 2018, 195, 340-353. [CrossRef]

33. United Nations Department of Economic and Social Affairs. The Sustainable Development Goals Report 2016; United Nations: New York, NY, USA, 2016; ISBN 978-92-1-101340-5.

34. GRI; UN Global Compact; WBCSD. SDG Compass-The Guide for Business Action on the SDGs. 2015. Available online: http://sdgcompass.org/ (accessed on 24 October 2018).

35. Gilbert, D.U.; Rasche, A.; Waddock, S. Accountability in a Global Economy: The Emergence of International Accountability Standards. Bus. Ethics Q. 2011, 21, 23-44. [CrossRef]

36. Ayuso, S.; Roca, M.; Arevalo, J.A. What Determines Principle-Based Standards Implementation? Reporting on Global Compact Adoption in Spanish Firms. J. Bus. Ethics 2016, 133, 553-565. [CrossRef]

37. Dominguez, N.; Mayrhofer, U. Internationalization stages of traditional SMEs: Increasing, decreasing and re-increasing commitment to foreign markets. Int. Bus. Rev. 2017, 26, 1051-1063. [CrossRef]

38. Dzikowski, P. A bibliometric analysis of born global firms. J. Bus. Res. 2018, 85, 281-294. [CrossRef] 
39. Coviello, N.; Kano, L.; Liesch, P.W. Adapting the Uppsala model to a modern world: Macro-context and microfoundations. J. Int. Bus. Stud. 2017, 48, 1151-1164. [CrossRef]

40. Håkanson, L.; Kappen, P. The 'Casino Model' of internationalization: An alternative Uppsala paradigm. J. Int. Bus. Stud. 2017, 48, 1103-1113. [CrossRef]

41. Buckley, P.J.; Doh, J.P.; Benischke, M.H. Towards a renaissance in international business research? Big questions, grand challenges, and the future of IB scholarship. J. Int. Bus. Stud. 2017, 48, 1045-1064. [CrossRef]

42. Santangelo, G.D.; Meyer, K.E. Internationalization as an evolutionary process. J. Int. Bus. Stud. 2017, 48, 1114-1130. [CrossRef]

43. Hennart, J.F. The theoretical rationale for a multinationality-performance relationship. Manag. Int. Rev. 2007, 47, 423-452. [CrossRef]

44. Hsu, W.-T.T.; Chen, H.-L.L.; Cheng, C.-Y.Y. Internationalization and firm performance of SMEs: The moderating effects of CEO attributes. J. World Bus. 2013, 48, 1-12. [CrossRef]

45. Lindstrand, A.; Hånell, S.M. International and market-specific social capital effects on international opportunity exploitation in the internationalization process. J. World Bus. 2017, 52, 653-663. [CrossRef]

46. Velez, M.L.; Sanchez, J.M.; Florez, R.; Alvarez-Dardet, C. How control system information characteristics affect exporter-intermediary relationship quality. Int. Bus. Rev. 2015, 24, 812-824. [CrossRef]

47. Prashantham, S.; Birkinshaw, J. MNE-SME cooperation: An integrative framework. J. Int. Bus. Stud. 2019, 1-15. [CrossRef]

48. Rugman, A.M.; Verbeke, A. Subsidiary-specific advantages in multinational enterprises. Strateg. Manag. J. 2001, 22, 237-250. [CrossRef]

49. Bell, J.; McNaughton, R.; Young, S.; Crick, D. Towards an Integrative Model of Small Firm Internationalisation. J. Int. Entrep. 2003, 1, 339-362. [CrossRef]

50. Kano, L.; Verbeke, A. Theories of the multinational firm: A microfoundational perspective. Glob. Strategy J. 2019, 9, 117-147. [CrossRef]

51. Van Zanten, J.A.; van Tulder, R. Multinational enterprises and the Sustainable Development Goals: An institutional approach to corporate engagement. J. Int. Bus. Policy 2018, 1, 208-233. [CrossRef]

52. Maksimov, V.; Wang, S.L.; Luo, Y. Reducing poverty in the least developed countries: The role of small and medium enterprises. J. World Bus. 2017, 52, 244-257. [CrossRef]

53. Westhead, P.; Wright, M.; Ucbasaran, D. The internationalization of new and small firms: A resource-based view. J. Bus. Ventur. 2001, 16, 333-358. [CrossRef]

54. Ruzzier, M.; Hisrich, R.D.; Antoncic, B. SME internationalization research: Past, present, and future. J. Small Bus. Enterp. Dev. 2006, 13, 476-497. [CrossRef]

55. Kovtun, A. Corporations' Internationalization and the Adoption of CSR Practices. J. Glob. Bus. Community 2013, 4, 1-14.

56. Oláh, J.; Kovács, S.; Virglerova, Z.; Lakner, Z.; Kovacova, M.; Popp, J. Analysis and Comparison of Economic and Financial Risk Sources in SMEs of the Visegrad Group and Serbia. Sustainability 2019, 11, 1853. [CrossRef]

57. Johanson, J.; Vahlne, J.E. The Uppsala internationalization process model revisited: From liability of foreignness to liability of outsidership. J. Int. Bus. Stud. 2009, 40, 1411-1431. [CrossRef]

58. Joensuu-Salo, S.; Sorama, K.; Viljamaa, A.; Varamäki, E. Firm Performance among Internationalized SMEs: The Interplay of Market Orientation, Marketing Capability and Digitalization. Adm. Sci. 2018, 8, 31. [CrossRef]

59. Kamakura, W.A.; Ramón-Jerónimo, M.A.; Gravel, J.D.V. A dynamic perspective to the internationalization of small-medium enterprises. J. Acad. Mark. Sci. 2012, 40, 236-251. [CrossRef]

60. Schweizer, R. The internationalization process of SMEs: A muddling-through process. J. Bus. Res. 2012, 65, 745-751. [CrossRef]

61. Nisar, S.; Boateng, A.; Wu, J.; Leung, M. Understanding the motives for SMEs entry choice of international entry mode. Mark. Intell. Plan. 2012, 30, 717-739. [CrossRef]

62. Cerrato, D.; Depperu, D. Unbundling the construct of firm-level international competitiveness. Multinatl. Bus. Rev. 2011, 19, 311-331. [CrossRef]

63. Buckley, P.J. The theory of international business pre-Hymer. J. World Bus. 2011, 46, 61-73. [CrossRef]

64. Vahlne, J.E.; Johanson, J. From internationalization to evolution: The Uppsala model at 40 years. J. Int. Bus. Stud. 2017, 48, 1087-1102. [CrossRef]

65. Chandra, Y.; Wilkinson, I.F. Firm internationalization from a network-centric complex-systems perspective. J. World Bus. 2017, 52, 691-701. [CrossRef] 
66. Kuivalainen, O.; Sundqvist, S.; Saarenketo, S.; McNaughton, R. Internationalization patterns of small and medium-sized enterprises. Int. Mark. Rev. 2012, 29, 448-465. [CrossRef]

67. Kalinic, I.; Forza, C. Rapid internationalization of traditional SMEs: Between gradualist models and born globals. Int. Bus. Rev. 2012, 21, 694-707. [CrossRef]

68. Kontinen, T.; Ojala, A. Internationalization pathways among family-owned SMEs. Int. Mark. Rev. 2012. [CrossRef]

69. Gerschewski, S.; Rose, E.L.; Lindsay, V.J. Understanding the drivers of international performance for born global firms: An integrated perspective. J. World Bus. 2015, 50, 558-575. [CrossRef]

70. Child, J.; Hsieh, L.H.Y. Decision mode, information and network attachment in the internationalization of SMEs: A configurational and contingency analysis. J. World Bus. 2014, 49, 598-610. [CrossRef]

71. D'Angelo, A.; Majocchi, A.; Buck, T. External managers, family ownership and the scope of SME internationalization. J. World Bus. 2016, 51, 534-547. [CrossRef]

72. Child, J.; Hsieh, L.; Elbanna, S.; Karmowska, J.; Marinova, S.; Puthusserry, P.; Tsai, T.; Narooz, R.; Zhang, Y. SME international business models: The role of context and experience. J. World Bus. 2017, 52, 664-679. [CrossRef]

73. Cerrato, D.; Crosato, L.; Depperu, D. Archetypes of SME internationalization: A configurational approach. Int. Bus. Rev. 2016, 25, 286-295. [CrossRef]

74. Freixanet, J. Export promotion programs: Their impact on companies' internationalization performance and competitiveness. Int. Bus. Rev. 2012, 21, 1065-1086. [CrossRef]

75. Dominguez, N. Agences de promotion et processus internationalisation des PME: Bénédiction ou malédiction? J. Int. Entrep. 2018, 16, 58-81. [CrossRef]

76. Fritz, M.; Schiefer, G. Innovation and System Dynamics in Food Networks. Agribusiness 2008, 24, 301-305. [CrossRef]

77. Schiefer, J.; Hartmann, M. Determinants of Competitive Advantage for German Food Processors. Agribusiness 2008, 24, 306-319. [CrossRef]

78. Weaver, R.D. Collaborative Pull Innovation: Origins and Adoption in the New Economy. Agribusiness 2008, 24, 388-402. [CrossRef]

79. Batterink, M.; Wubben, E.; (Onno) Omta, S. Factors related to innovative output in the Dutch agrifood industry. J. Chain Netw. Sci. 2006, 6, 31-44. [CrossRef]

80. Hervas-Oliver, J.L.; Sempere-Ripoll, F.; Boronat-Moll, C. Process innovation strategy in SMEs, organizational innovation and performance: A misleading debate? Small Bus. Econ. 2014, 43, 873-886. [CrossRef]

81. Cembalo, L.; Cicia, G.; Giudice, T.D.; Scarpa, R.; Tagliafierr, C. Beyond Agropiracy: The Case of Italian Pasta in the United States Retail Market. Agribusiness 2008, 24, 403-413. [CrossRef]

82. Maté-Sánchez-Val, M.; Harris, R. The paradox of geographical proximity for innovators: A regional study of the Spanish agri-food sector. Land Use Policy 2018, 73, 458-467. [CrossRef]

83. Singh, R.; Subrahmanya, M.H.B. Network Cooperation, Innovation, Internationalization and Economic Performance of SMEs: An Exploratory Study. Asian J. Innov. Policy 2018, 7, 461-488. [CrossRef]

84. Fritz, M.; Canavari, M. Management of Perceived e-Business Risks in Food- Supply Networks: E-Trust as Prerequisite for Supply-Chain System Innovation. Agribusiness 2008, 24, 355-368. [CrossRef]

85. Alarcón, S.; Arias, P. The public funding of innovation in agri-food businesses. Span. J. Agric. Res. 2018, 16, 1-13. [CrossRef]

86. Gomez-Conde, J.; Lopez-Valeiras, E.; Ripoll-Feliu, V.M.; Gonzalez-Sanchez, M.B. El efecto mediador y moderador de la internacionalizacion en la relacion entre los sistemas de control de gestion y el compromiso con la innovacion. Rev. Contab. 2013, 16, 53-65. [CrossRef]

87. Vélez, M.L.; Sánchez, J.M.; Álvarez-Dardet, C. Management control systems as inter-organizational trust builders in evolving relationships: Evidence from a longitudinal case study Q. AOS 2008, 33, 968-994. [CrossRef]

88. Jack, L.; Florez-Lopez, R.; Ramon-Jeronimo, J.M. Accounting, performance measurement and fairness in UK fresh produce supply networks. Account. Organ. Soc. 2018, 64, 17-30. [CrossRef]

89. Love, J.H.; Roper, S. SME innovation, exporting and growth: A review of existing evidence. Int. Small Bus. J. Res. Entrep. 2015, 33, 28-48. [CrossRef]

90. Kataike, J.; Gellynck, X. 22 Years of Governance Structures and Performance: What Has Been Achieved in Agrifood Chains and Beyond? A Review. Agriculture 2018, 8, 51. [CrossRef] 
91. Chenhall, R.H.; Morris, D. The Impact of Structure, Environment, and Interdependence on the Perceived Usefulness of Management Accounting Systems. Account. Rev. 1986, 61, 16-35.

92. Bouwens, J.; Abernethy, M.A. The consequences of customization on management accounting system design. Account. Organ. Soc. 2000, 25, 221-241. [CrossRef]

93. Simons, R. Levers of Control: How Managers Use Innovative Control Systems to Drive Strategic Renewal; Harvard University Press: Boston, MA, USA, 1995; ISBN 9780875845593.

94. Bisbe, J.; Otley, D. The effects of the interactive use of management control systems on product innovation. Account. Organ. Soc. 2004, 29, 709-737. [CrossRef]

95. Bell, J.; Crick, D.; Young, S. Small firm internationalization and business strategy: An exploratory study of 'knowledge intensive' and 'traditional' manufacturing firms in the UK. Int. Small Bus. J. 2004, 22, 23-56. [CrossRef]

96. Yin, R.K. Case Study Research: Design and Methods, 2nd ed.; Sage: Thousand Oaks, CA, USA, 1994; ISBN 0803956630.

97. Andrade, A.D. Interpretive Research Aiming at Theory Building: Adopting and Adapting the Case Study Design. Qual. Rep. 2009, 14, 42-60.

98. Alcácer, J.; Cantwell, J.; Piscitello, L. Internationalization in the information age: A new era for places, firms, and international business networks? J. Int. Bus. Stud. 2016, 47, 499-512. [CrossRef]

99. Baxter, P.; Jack, S. The Qualitative Report Qualitative Case Study Methodology: Study Design and Implementation for Novice Researchers. Qual. Rep. 2008, 13, 544-559.

100. Castilla-Polo, F.; Gallardo-Vázquez, D.; Sánchez-Hernández, M.I.; Ruiz-Rodríguez, M.C. An empirical approach to analyse the reputation-performance linkage in agrifood cooperatives. J. Clean. Prod. 2018, 195, 163-175. [CrossRef]

101. Mugera, A.W.; Bitsch, V. Managing Labor on Dairy Farms: A Resource-Based Perspective with Evidence from Case Studies. Int. Food Agribus. Manag. Rev. 2005, 8, 79-98.

102. Westgren, R.; Zering, K. Case study research methods for firm and market research. Agribusiness 1998, 14, 415-423. [CrossRef]

103. McAdam, M.; McAdam, R.; Dunn, A.; McCall, C. Regional Horizontal Networks within the SME Agri-Food Sector: An Innovation and Social Network Perspective. Reg. Stud. 2016, 50, 1316-1329. [CrossRef]

104. Bertolini, P.; Giovannetti, E. Industrial districts and internationalization: The case of the agri-food industry in Modena, Italy. Entrep. Reg. Dev. 2006, 18, 279-304. [CrossRef]

105. O'Dwyer, B. Qualitative Data Analysis: Illuminating a Process for Transforming a 'Messy' but 'Attractive' 'Nuisance'. In The Real Life Guide to Accounting Research; Elsevier Ltd.: Oxford, UK, 2004; ISBN 0080439721.

106. Aznar-Sánchez, J.A.; Galdeano-Gómez, E.; Pérez-Mesa, J.C. Intensive Horticulture in Almería (Spain): A Counterpoint to Current European Rural Policy Strategies. J. Agrar. Chang. 2011, 11, 241-261. [CrossRef]

107. Junta de Andalucia. Informe Economico de Andalucia. 2017; Junta de Andalucia: Seville, Spain, 2018; ISBN 978-84-09-03571-7.

108. Rodríguez-Rodríguez, M.; Galdeano-Gómez, E.; Carmona-Moreno, E.; Godoy-Durán, Á. Environmental Impact, Export Intensity, and Productivity Interactions: An Empirical Index Analysis of the Agri-Food Industry in Spain. Can. J. Agric. Econ. 2012, 60, 33-52. [CrossRef]

109. O'Connor, A.; Parcha, J.M.; Tulibaski, K.L.G. The Institutionalization of Corporate Social Responsibility Communication: An Intra-Industry Comparison of MNCs' and SMEs' CSR Reports. Manag. Commun. Q. 2017, 31, 503-532. [CrossRef]

110. Auerbach, C.; Silverstein, L.B. Qualitative Data: An Introduction to Coding and Analysis; New York University Press: New York, NY, USA, 2003; ISBN 9780814706947.

111. Dubois, A.; Gadde, L.-E. Systematic combining: An abductive approach to case research. J. Bus. Res. 2002, 55, 553-560. [CrossRef]

112. Eisenhardt, K.M. Building Theories from Case Study Research. Acad. Manag. Rev. 1989, 14, 532-550. [CrossRef]

113. Pauwels, P.; Matthyssens, P. The Architecture of Multiple Case Study Research in International Business. In Handbook of Qualitative Research Methods for International Business; Welch, C.A., Piekkari, R., Eds.; Edward Elgar Publishing: Cheltenham, UK, 2004; pp. 125-143. ISBN 9781781954331.

114. Glaser, B.G.; Strauss, A.L. The Discovery of Grounded Theory: Strategies for Qualitative Research; Transaction Publishers: Piscataway, NJ, USA, 1999; ISBN 0-202-30260-1. 
115. Malterud, K.; Siersma, V.D.; Guassora, A.D. Sample Size in Qualitative Interview Studies: Guided by Information Power. Qual. Health Res. 2016, 26, 1753-1760. [CrossRef]

116. Crouch, M.; McKenzie, H. The logic of small samples in interview-based qualitative research. Soc. Sci. Inf. 2006, 45, 483-499. [CrossRef]

117. Pedroso, C.B.; da Silva, A.L.; Tate, W.L. Sales and Operations Planning (S\&OP): Insights from a multi-case study of Brazilian Organizations. Int. J. Prod. Econ. 2016, 182, 213-229. [CrossRef]

118. Boxer, R.; Perren, L.; Berry, A. SME managing director and non-executive director trust relations: The dynamic interplay between structure and agency. Int. Small Bus. J. Res. Entrep. 2015, 34, 369-386. [CrossRef]

119. Mistry, J.J. Supply Chain Management: A Case Study of an Integrated Lean and Agile Model. Qual. Res. Account. Manag. 2005, 2, 193-215. [CrossRef]

120. McKitterick, L.; Quinn, B.; Tregear, A. Trust formation in agri-food institutional support networks. J. Rural Stud. 2019, 65, 53-64. [CrossRef]

121. Frasquet, M.; Dawson, J.; Calderón, H.; Fayos, T. Integrating embeddedness with dynamic capabilities in the internationalisation of fashion retailers. Int. Bus. Rev. 2018, 27, 904-914. [CrossRef]

122. Saldana, J. Fundamentals of Qualitative Research; Oxford University Press: New York, NY, USA, 2011; ISBN 9780199838356.

123. Galdeano-Gómez, E.; Pérez-Mesa, J.C.; Giagnocavo, C.L. Food exporters and co-opetition relationships: An analysis on the vegetable supply chain. Br. Food J. 2015, 117, 1596-1609. [CrossRef]

124. Giagnocavo, C.; Gerez, S.; Valencia, D. Paths to cooperative survival: Structure, strategy and regeneration of fruit and vegetables cooperatives in Almeria and Valencia, Spain. Ann. Public Coop. Econ. 2014, 85, 617-639. [CrossRef]

125. Nastis, S.A.; Mattas, K.; Baourakis, G. Understanding Farmers' Behavior towards Sustainable Practices and Their Perceptions of Risk. Sustainability 2019, 11, 1303. [CrossRef]

126. Baregheh, A.; Rowley, J.; Hemsworth, D. The effect of organisational size and age on position and paradigm innovation. J. Small Bus. Enterp. Dev. 2016, 23, 768-789. [CrossRef]

127. Ferrara, G. Innovation in Agro-Food: A Geographical Perspective. J. Food Prod. Mark. 2018, $24,117-124$. [CrossRef]

128. Wright, M.; Westhead, P.; Ucbasaran, D. Internationalization of small and medium-sized enterprises (SMEs) and international entrepreneurship: A critique and policy implications. Reg. Stud. 2007, 41, 1013-1030. [CrossRef]

129. Prashantham, S.; Dhanaraj, C. MNE ties and new venture internationalization: Exploratory insights from India. Asia Pac. J. Manag. 2015, 1848, 901-924. [CrossRef] 